\section{Made in Latin America*}

\section{ABSTRACT}

The text elaborates on the contribution of Latin American intelectuals to the development of new theoretical perspect-ives to reception studies.

\section{RESUMO}

Este texto discute a contribuição de intelectuais latino-americanos para o desenvolvimento de novas perspectivas teóricas para os estudos de recepção.

\section{KEY WORDS (PALAVRAS-CHAVE)}

- Reception studies (Estudos de recepção)

- Latin America (América Latina)

- Communication theory (Teorias da comunicação) “...los países de Latinoamérica, definidos aquí como las veinte antiguas colonias españolas y portuguesas de las Américas y el Caribe..."1

"LA RECEPCIÓN YA NO ALCANZA"- by that title the Argentine researcher Sergio Caletti (1992) wrote a severe criticism of the reception studies, indirectly targeting Latin-American perspectives. It began with a disagreement about their denomination as paradigmatic studies and by criticising the disparity of these new perspectives ${ }^{2}$, the only common issues of which are the rupture with the mechanical or determinist premises. He criticizes, therefore, the lacking of organic development of certain theses and also the several attempts at what he calls "readings", which seek to replace social theories that pay attention to structures and social space.

To him, there isn't any reception theory, only an "ideology of reception" - one that he considers to be not much discussed and criticized, specially in Latin America, where it found itself in a vacuum, due to the lack of confrontation with others theories. He also believes it, because the studies of reception were institutionalized in the communication schools, as much in the research level as in the teaching. ${ }^{3}$

While outlining his critique of reception research, Caletti recognizes the advancement brought by them to communication studies, but defends "un proyecto teórico que haga de nuestros enfoques y perspectivas una ventana abierta a los movimientos que hoy atraviesan las ciencias de lo humano, y en cuyo despliegue apostemos a disolver la falsa especificidad de lo comunicacional" (Caletti, 1992: 40). Hence, the author defends the inclusion of communication research in a general theory of meaning production, although he doesn't point out how and where he would start it.

On the other hand Maria Immacolata 
Lopes, a Brazilian researcher, points at the debility of the interpretative theoretical framework as an international tendency that hasn't transcended the accumulation of empirical evidence about media audiences, by missing the complexity and critical character of these. She points out as exceptions the perspectives that join the cultural approaches.Those perspectives look for a "comprehensive theory" of reception, which means to articulate a social structures theory, a theory of discourse or communication and theory of socio-cultural and social-psychological dispositions, like proposed by Klaus Jensen and Erik Rosengren in a classic essay about audience studies (1990).

In this sense, she recognizes the development of the Latin-American research identified in Jesús Martin- Barbero's, Jorge González's, Valério Fuenzalida's, and Guillermo Orozco's works, beside others, saying that they pass the simple conjugation between qualitative analysis of audience and media content analysis. However, in a later essay (Lopes, 1995), joining parts of the criticism by Caletti (1992), she demands of these same tendencies their inclusion in the recent theories of social classes, which review the issue of the social determinations.

She also says that the "multi-mediations" ${ }^{4}$ analysis must operate with a basic structural principle to articulate the mediations, and must also be considered the power in the daily relationship and communication practices.

She proposes, then, a cultural and political criticique of reception studies, as brought forward by Cultural Studies in the beginning, when they talked about the theoretical nexus between the political and cultural sphere of power in the daily practices.

In her critique, the most prominent concept is the social classes, which is present as a structural element in three items of the formulation proposed by her.

The two authors presented above criticize the most recent phase of the audience research's development accomplished in Latin America. It's important to point out, however, that a Latin-American production in the Communication Theory field begun to receive both more internal ${ }^{5}$ and international ${ }^{6}$ attention, paradoxically, when it turns to its own reality as an explicative theoretical axis of its social-cultural and communicational phenomena.

This scenery started sketch in the early 1980 's, when a series of internal and external conditions to scientific field combined and render the appearance of a particularly Latin American discussion (Orozco In Jacks, 1993: 25). "Razones teóricas, experiencias culturales y hechos sociales se entrecruzan ahí catalizando el nuevo sentido de los procesos de comunicación en las sociedades de fin de siglo", says Martin- Barbero (1991:4), refering to the research developed in Latin America.

The theoretical reasons refer to the insufficiency of the "imported models", broadly adopted in the researches until then, conceived "in" and "for" others realities. Besides this, they are not able to support the analysis of the daily life. In Latin America people were living, at that time, the others two reasons -cultural experiences and social facts- to the changing of route pointed by Martin-Barbero like, for example, the redemocratization of Latin-America societies, the new social movements surged in the periphery, between the young people and women, between Afro-Americans and Indians, besides others.

From this change, to understand these new social-political and cultural circumstances, emerges the necessity to point out some aspects a little or inadequately considered by the previous perspectives. The social-cultural context, the social interactions and the subjects become relevant, consequently, the new perspective of the reception studies ${ }^{7}$, which basic lines will be commented further, retaking two essays published previously (Jacks, 1995 and 1996).

\section{Reception studies within Latin America: an overview}

The inaugural studies were done below 
the influence of functionalism and semiology theories. After the adoption of the He-gemony's concept, conceived by Antonio Gramsci ${ }^{8}$, and the cultural vision of the communication media supported by Cultural Studies, several others theoretical-methodological approaches were developed. These approaches have as an objective surpass the previous perspective in a attempt to understand not "what the media does with the receivers" or "what the receivers do with the media", but "the relation involved in this process"(Orozco,1996:31).

We can emphasize the perspectives known as "cultural consumption" developed by the Argentinean, who now lives in Mexico, Néstor García Canclini; "cultural fronts" proposed by Jorge González when he was coordinating the Programa Cultura at Colima University in Mexico; "active reception" worked in the Center of Indagación y Expresión Cultural y Artística (CENE$\mathrm{CA} /$ Chile) when it was by the coordination of Valério Fuenzalida and Maria Elena Hermosilla; "social use of the media" conceived by Jesús Martín-Barbero, a Spanish who now lives in Colombia and "integral approach to reception" a theoretical-methodological model developed by Guillermo Orozco, during the time he coordinated the Programa Institucional de Investigación en Comunicación y Practicas Sociales in the Ibero-American University in Mexico City. Among these perspectives, there are some which the focus is to study the reception process, in general of television, others embrace a more open context to the approaching of relations between culture and communication.

The Cultural Consumption's perspective is to build a social-cultural theory of consumption to approach the communication process and the reception of symbolic goods. For that, Canclini judge the consumption as "el conjunto de procesos socioculturales en que se realizan la apropriación y los usos de los productos" (1993:24) surmounting the consumption notion as an individual and irrational act moved by desire, which is stimulated only by the personal taste. His idea leaves behind the frankfurtian legacy to incorporate the complexity of the daily life, the creativity of the people and the interactive relation with media.

The consumption seen as an integrant part of the production cycle and of the goods circulation makes their complex mechanisms more visible, which exceed the simple idea of "consuming compulsion". However, this idea doesn't give power to the consumers, it only organize the reasons, conditions and sceneries where the consumption is done, reveling the sense of what constitute itself.

It is an interdisciplinary propose, because acclaims specially the sociologists, the people who study communication and the anthropologists to study the consumption phenomenon, linking several aspects: economical, sociological, anthropological and psychoanalytical, in their derivations. For that Canclini proposed the articulation of six theories, by the argument that none is self-sufficient to explain the consumption: a) "place of reproduction of the forces of production and the expansion of the capital", b) "place where the classes and the groups compete for the appropriation of the social products", c) "place of social differentiation and symbolic distinction between the groups", d) "place for integration and communication interchanges", e) "scenery where the desires become concrete" and f) "ritualistic processes" (Canclini, 1992).

"Cultural Fronts" is the theoretical- methodological model conceived by Jorge González, resulted of empirical studies about the relation of the popular and massive culture with their public, from a social-anthropological point of view. In other words, the analysis is done through the multi-dimensionality of the spatial and temporal relation of these symbolic forms with the society.

This model brings as basic premise an adaptation of the Hegemony concept by Gramsci, to explain how coalition of power reaches the consensus among subordinated groups, through the incorporation, in 
the public sphere, of cultural symbols of these groups, in manner to make possible its identification. Also, it is used the notion of field proposed by Pierre Bourdieu, because understands the culture as a strength system developed in the dispute for the cultural hegemony ${ }^{9}$, where is included the cultural industry.

Thus, the approach of social-cultural identity proposed by this perspective considers the culture as a arena for confrontation of diverse "cultural fronts", each of those disputing the consent/acceptation and recognition of its cultural identity by other "fronts". In mass media terms, he considers them essential to understand the contemporary culture and also the popular cultures, because there is a point where both "touch" the cultural industries. This is a relevant aspect to the reception studies, because it is reflected in the search of definition or redefinition of audiences when we talk about their social-cultural identities related with massive culture.

The presuppositon which drives the audience study is that "todo el texto o discurso especializado que emana de los campos nunca es recibido por individuos aislados, porque siempre están insertos en diversas redes ideológicas que constituyem las formas de convivencia social elemental, en cuyo seno se genera, se digiere, desconstruye, se recicla y se reconstruye el discurso de los campos, todos los días, día con día" (González, 1994: 265).

"Active Reception" is the investigation line development by CENECA through the Programa de Educación para la Recepción Activa de la TV.

The theoretical presuppositions that helped to refute the linear analysis models were empirically tested, exploring the relation between messages and the TV viewers. They are: the group's influence in the construction of the meaning to what is appropriated from television and the TV as a "hetero-discursive" media that concentrate many aspects of contemporary culture.

Among the hypothesis tested about the cultural influence of television are: multi-relationship established with the media through the time and through the different programming (constructivist reception); emotional relationship more than rational and analytic, determining also by the gender of the programming; the "domicile" reception request its own aesthe-tics(different from the movies) determined by other kind of fruition and by the relation with the media; the audience's relation with the TV, the importance of the social-cultural context (social practices), which overpass the referents and the intention of senders.

The theoretical displacements realized by the researches from CENECA illuminated some opaque zones of the reception phenomenon and put in doubt the omnipotent and monolithic power of the television. They repel the vision of receivers as "depositary" and the context as "intervenient variables". They understood that the reception process and the cultural influence of television need to be placed in historical perspective, also that the reception is a constructive, dialectic and conflictive process.

The most criticize point of this line of thought is its eminently pedagogical character and its methodological treatment in artificial situation of reception.

Social use of the media or Mediation Theory, conception of Martin-Barbero, comes from the articulations between the communication practices and the social movements, considering the different social time and the plurality of the cultural matrix. The proposed merged from the necessity to understand the insertion of the Latin America popular stratum in the context between the sub development and accelerated process of modernization, that implies in the appearance of new identities and new social subjects, forged, in specially, by the communication technology.

For the communication research it brings, therefore, several implication among them the displacement from the production axis analysis, to the ambit of 
consumption, to check what the receivers do with the massive contents in their daily practices.

The "use", therefore, are inalienable of the social-cultural context of the receivers, who rebuilt, redenoted the massive contents alike its cultural experience, that support their appropriations. To consider the receiver producing meaning as the senders is the principal change brought for this focus, that identify the quotidian as the place to be researched and the consumption as analytical category. Martin-Barbero says: "el consumo no é solo reproducción de fuerzas, sino también producción de sentidos: lugar de una lucha que no se agota en la posesión de los objetos, pues pasa aún más decisivamente por los usos que les dan forma social y en los que se inscriben demandas y dispositivos de acción que provienen de diferentes competencias culturales" (1987: 231). For that, Martin-Barbero proposes the study of three kinds of mediations, as a form to capture the cultural references where they are experienced: the family's quotidian, the social time and the cultural competences.

Mediation, the fundamental concept in Martin-Barbero's Theory, must be understood as a group of influences that structure, organize and reorganize the receiver's reality perception, capable also to give value to this reality, implicitly or explicitly. The mediations produce and reproduce the social meanings, being the category that helps to understand the interactions between the production and media reception, for that reason "la investigación de los usos nos obliga entonces a desplazarnos del espacio de los medios al lugar em que se produce su sentido" (idem: 213)

"The integral approach to reception", a line developed by Guillermo Orozco follows most of the presuppositions presented above, besides integrating the concept of "rule" from the Social Structure Theory of Giddens ${ }^{10}$.

The question that orients this methodological-theoretical effort is: "how is done the interaction between TV and audience?", which answer started to be looked for by the British Cultural Studies and in LatinAmerican by authors as Fuenzalida and Hermosilla, according to Guillermo Orozco

Research in this perspective implies to assume the audience group as subject and consider it in "situation", consequently, determined individual and collectively. Implies also to see it in construction by different processes, and in constant changing. It implies to consider, therefore, the reception process as a resultant of the interaction among receiver/TV/mediations, that go all together in the continuous act to watch TV, but at the same time to exceed it.

In this sense, TV is also a mediation, because as a social institution it produces meaning that receive, or not, legitimacy from its audience. Tv reproduces the reality and, in the same time, provokes rational and emotional reactions in the receivers.

The receivers also realize mediations, it has psychological character, determinate by the social-cultural environment, in a constant and dialectic process. Orozco calls them by Individual Mediations, which shelter the cognitive and the structural ones.

During the reception time acts also the "situational mediation", which analysis can demonstrate how it occurs and what does it mean. It can identify as the TV's emission finds the receiver: alone or accompany, with exclusive attention or dispersed, interchanging considerations with others TVviewers or not, in the social space or in the house intimacy, etc. It should be considered also that they are much more than single TV-viewers, because the institutions that they belong - school, job, church, parties, family, etc - are fundamental to the reception process. The "institutional mediations" take part in the relation of people with the TV's discourse, because by them the subjects interact, interchange, produce and reproduce senses and meanings.

Claudia Herrán Monedero, Colombian researcher, in an article called "Un salto no dado: de las mediaciones al sentido" (1994), presents an analyses that considering the li- 
mitations of the reception studies, focusing on the model of Multimediations ${ }^{11}$.

Based on Pierre Bourdieu sociological approach, she points the lacking of the society framework perspective in the researches of media reception supported by the model referred above, what results in the impossibility to understand how the communicative process gets in the global symbolic systems, which creates the social sense.

The authoress considers subjective the social conception used by the Model of Multimediations, because it doesn't consider the social space occupied by the agents (receivers). This localization would identify the access to the cultural, educational, economical and symbolic sources, what Bourdieu calls cultural capital, which determinate a specific cultural competence, an "habitus".

For her to consider the receiver just as a social-cultural determinated subject as the model of Multimediation does, is insufficient because the analysis about their social action results in a free and rational capacity as central in the process and it isn't true. She also criticizes what the Model consider "institutional mediations" - family, school, media, etc -once it is not being realized the function that play inside of the social space, in other words, claims the use of the concept of "field" from the sociologist already mentioned.

In short, what suggests is that the Multi- Mediations Theory is insufficient to understand the global processes of meaning production that are wider than the relation with media, by considering this type of research very restrictive and focused. The authoress claims an other theoretical construction to understand the social action of the subject, what would result a different approximation of the society and of the rule exerted by the communication in this context.

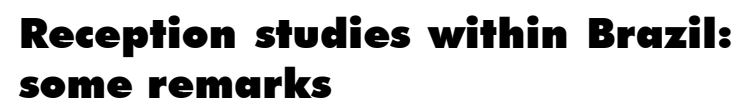

In Brazil, there are a few researchers ${ }^{12}$ dedicated to reception studies and they aren't congregated around researches centers.

To the Brazilian researcher, Maria Immacolata Lopes(1994:179), the Brazilian case contrast with the remaining of the Latin-continent, that have groups of researchers working in integrated and multidisciplinary projects in this area. Those are the cases about soap opera researches in Colombia(Martin-Barbero, 1987) and in Mexico (González, 1991), about active reception in Chile(Fuenzalida, 1987) and about children and TV in Mexico(Orozco, 1992), besides others"

The reception researches, in Brazil, are isolated initiative ${ }^{13}$, what revels a discontinuity of the production in this area and, not rare, of the interest of the researchers, who abandon the issue for others projects. With all that, until the moment there are no theoretical-methodological perspectives founded in Brazil, which identify its production, that is, consequently, tributary of the tradition that has developed in Latin America, how we will see later.

Shortly, we can point as pioneers the works from 70's, mostly developed out from the communication schools, still with the strong influence from the Frankfurt Theory, from the semiology and from Theory of Effects, emphasizing the messages ideologies, however, emerging, in some of them, the influences from Antonio Gramsci and Pierre Bourdieu works.

Among the works which contributed in some degree to the development of the reception research, in this stage, we can find: "A noite da madrinha" (Miceli, 1972), "A TV e o quadro de referência sócio-cultural: o público dos telepostos de São Luis do Maranhão" (Camargo, 1972), "Televisão e consciência de classe" (Da Viá, 1977), "Por trás das ondas da Rádio Nacional" (Goldfeder, 1980) ${ }^{14}$, "Cultura de Massa e Cultura Popular. Leitura de operárias" (Bosi, 1972) e “O paraíso via Embratel" (Milanesi, 1978).

The importance of some of these 
works is the fact that they attest the place acquired by the media in that moment of the Brazilian society, more than by their theoretical-methodological ideas. The Sergio Miceli's and Miriam Goldfeder's works, the first analyzing a restrict audience (the audience of TV shows), the second recovering the radio receivers (in specialized magazines, in fan-clubs documents and in analysis of audience shows) -, introduced a new theoretical debate in the context of massive communications studies. The Bosi's work also turned to be a classic in the approaching of the relation between mass communication and popular culture.

In the communication area, specifically, the most important experience, although, with a pedagogical and didactic nature - indicated to teachers, community's and popular movement's leaders, etc - have been developed below the inspiration on "Pedagogia do Oprimido" by Paulo Freire. It is named "Criticism Leisure in Communication" (LCC), led by Brazilian Catholic Union of Social Communication (UCBC) in partnership with a Catholic Church wing. The project initiated in 1979 is going on, but less strong than before. It has been suffering many changes in its initial proposes (vvaa:1992). One of its principal strategies was the publication of "Para Uma Leitura Crítica", a collection of booklets, prepared by communication theorists and compounded of manuals to guide the "reading" of TV, newspaper, comic books and advertisement.

In the early 80 's, part of the researches founded a new tendency in the communication studies, because they change the approaches of the reception analysis, then in this sense, they are also marked by being the pioneer. Among the examples that will come, however, there are some that does not bring a new conception, they are quoted because they document the production from that time. The researches are: "Leitura Social da Novela das Oito" (Leal, 1986) inserted in the social anthropological field, achieved an ethnography of audien- ce comparing the reception of soap opera in different social classes; "Muito Alem do Jardim Botânico" (Silva, 1985) analyses the reception of news programs by workers of two villages, through an participatory action research; "Ideologia Sexual dos Gigantes" (Sarques, 1981) analyzed the reception of a soap opera by the point of view of the sexual moral; "O Pica-Pau: Herói ou Vilão?" (Pacheco, 1975), which referential is the social psychology theory, researched the reception of cartoons among kids of two different social classes, with the objective to discover the ideological effects of the program; "O Mito na Sala de Jantar" (Fischer, 1984) analyzed the children and adolescents' discourse about their preferences, critics and expectations about TV's programming, searching for the contemporary myths created by it; "O Rádio dos Pobres" (Lopes,1988) studied the ideological effects of the popular discourse from the radio, among the marginal population living in São Paulo city.

In the end of this decade, others works, as the previous, made for thesis and dissertations came out: "Telenovela e Doméstica: da catarse ao distanciamento" (Bem,1978) analyzes the soap opera in the daily space of servants from rural regions; "A TV Globo em dua comunidades rurais da Paraíba" (Trigueiro, 1987), approached by the conjugation of participant observation research and quantitative analysis, trying to know the social-cultural universe of the receivers; "Rosa Púrpura de cada dia: trajetória de vida e cotidiano de receptores de telenovela" (Sousa,1976) has a focus in the urban-industrial daily and in the genre differences in the reception process; "Elementos para a Democratização da Televisão do Brasil" (Tilburge, 1987) studies the complicity and seduction between the media and the receivers from popular classes, searching for a strategy to the democratization of the TV.

Analyzing the theoretical-methodological approaches ${ }^{15}$ of these works, we can establish that the "Latin-american theories" 
until the end of the 80's did not have determinant influence in Brazilian researches. The opposite, however, happened in the turning of the decade, when it started to be assimilated as a new referential because it focus was in cultural environment of receivers. It means to analyze the mediations, which configure the relation between viewers and media - and not only the ideological influence of media, the different "readings" of its discourse or just the activity of the audience - as the focus of earlier researches.In this way, is important to point out the influence of the Matin-Barbero's works, that introduced the concept of mediation, in the same manner as his studies about popular culture added to the contributions of Néstor García Canclini ${ }^{16}$, in special his studies about hybrid cultures and cultural consumption.

From this referential, by example, was researched the mediation of regional culture in "Querência. Cultura regional como mediação simbólica. Um estudo de recepção" (Jacks,1993) and the mediation of rural culture in "Cotidiano rural e recepção de TV: o caso Três Barras" (Ronsini, 1993), both with the objective to take the identity as axis of analysis and interpretation to understand audience's point of view. These two empirical studies can be considered belonging to a tradition of reception research started to be built in Latin-America after the 80's and in the Brazilian context after the 90's.

The 90's academic production on media reception, as one, is being mapped out and analyzed (Jacks,2003/2005 and Escosteguy, 2002), but we can anticipate that still persist quantitative and behaviorist studies and, even though, the LatinAmerican theories have a great influence, they are not assumed with the radicalism that the social-cultural focus proposed by mostly of the perspectives suggested. Most of them circumscribe to the very restrict ambit of the relation media-audience, which does not contemplate the complexity of the social meaning production.

The criticism here presented, concerned to the Latin-American and Brazilian context are differentiate from each other, but both bring as issue the consequences caused by the displacement from the logic of the determination to the mediation ones. In other words, without the social structure focus, the daily practices of the receivers result partly understood, because it takes just the strictly communicational aspect, forgetting the most wide social-cultural context, where all the meanings acquire sense.

In consequence, they claim a reception research that contribute to a new social-cultural comprehension of daily contemporary life phenomenon, to understand the rule of the communication process in a Theory of Social production of meaning, which one is not small, not even peripheral.According to the perspectives developed in this part of the world, we can realize that some criticized points have already been considered by some of them. If any perspective hasn't done that, at least the group of approaches as a whole has contributed to that, considering there is no theoretical-methodological incongruity among them - because they come from the same paradigmatic perspective- articulating among them- we can point to an answer that cross the limits indicated by the criticisms presented here .

\section{Notes}

* Tradução de Cora Efrom - Porto Alegre, março de 2004

1 Schlesinger and Morris (1997:55)

2 Exemplify the tendencies, mentioning the influence of Birmingham and Constanza, the last Wittgenstein and the Oxford's pragmatic, the theory of Bordieu's fields and the systemic North-American theory, the Focault and Deleuze's thought, Habermas' modernism, Pierce semiotics, some lines of psychoanalysis, the old theorists from Russian literature and the post-modernity interpreters.

3 What certainly is not the case of most Brazilian schools, by example, where the curriculum does not incorporate disciplines that talk about that issue and it isn't usually discussed in Theories of Communication Courses. 
4 Refers to a perspective proposed by Guillermo Orozco, which will be expanded on later.

5 Although in a unbalanced manner in differents countries of the region and among the regions of each country.

6 Many foreign researchers have interest for the LatinAmerica's research (Tufte, 1996; Schlesinger e Morris, 1997; Fox, 1988 e 1996; Mitchel e Einsiedel, 1995, Jones, 1996) and some scientific periodic published outside of Latin-America dedicated editions to this production lately (Telos, Borderlines, Media, Culture and Society, etc.), besides meetings promoted in Latin America and outside of it to discuss this issue.

7 It is discussed between the Brazilian researchers, as it is believed to happen in other countries, about the correct use of the word reception to refer to the people relation with the communication media. However, besides those critics, the word is still used to this type of research and phenomenon in the Brazilian research scenery.

8 José Aricó, in "Geografia de Gramsci na América Latina" (Coutinho and Nogueira, 1988) comments the impossibility of talking in a singular manner of the influence of this author in the continent, because of the several realities that took him to a plurality of appropriation of his theory.

9 González considers that "una reflexión filosófica hermenéutica- fenomenológica que alguma gente le ha dado por llamar las etnometodologías, las fenome-nologías sociológicas, la sociologia cognitiva, que es precisamente la sociologia del sentido común..." is also part of it. Apud Vélez, 1992:149

10 The concept was worked primarily by the north-American researcher James Lull who utilized as analytic instrument to explore the interaction between the macro and micro contexts in the media reception processes. To avoid dualism between macro and micro, Orozco considers these levels as "mediation source" (Orozco, 1994:71).

11 The Argentinean researcher, Florencia Saintout (1998), also made a severe critic to this model.

12 From 1769 thesis and dissertations defended in the Brazilian Post-graduation Programs in Communication, between 1992 and 1999, only 50 were about reception studies
13 The only experiences that put together the researchers of media reception are two Workshops constituted in annual congresses of the Brazilian Society of Communication Interdisciplinary of Studies (INTERCOM) and of the National Association of Post Graduation Programs in Communication (COMPÓS), when present their annual production. The Workshops, however, by its nature, are not configured around the shared theoretical-methodological perspectives. "Comunicação e recepção" a group formed by INTERCOM and "Mídia e Recepção" group from COMPÓS have recent constitution, the first in 1990, the second in 1992. The WGs from INTERCOM was closed in 2000, passing to be a thematic group in the WGs of Communication Theories.

14 The work was defended as a Master's essay in 1977, in the UNICAMP. All the works presented here are quoted with the publication year.

15 To a theoretical-methodological critics of the reception researches realized in the 80's, see: Escosteguy (1993).

16 In accordance with Lopes " it is, above all, inside of the popular cultural thematic that a complex and multifaceted reception theory started to be developed" (1994: 177.)

\section{References}

BEM, Arim Soares do. (1988) "Telenovela e doméstica: da catarse ao distanciamento". Dissertação de Mestrado. ECA/USP.

BOSI, Ecléa (1972) Cultura de Massa e Cultura Popular. Leitura de operárias. Rio de Janeiro. Vozes.

CALETTI, Sérgio (1992). "La recepción ya no alcanza", In CORTÉS, Carlos Luna (coord.) Generaciones de conoci-miento y formacion de comunicadores. México. FELAFACS.

CAMARGO, Nelly de (1972) "A TV e o quadro de referência sócio-cultural: o público dos telepostos de São Luis do Maranhão". Tese de doutorado. São Paulo. ECA/USP.

CANCLINI, Néstor García. (1993) El consumo cultural y su estudio en México: una propuesta teórica. México: CNCA.

COUTINHO, Carlos Nelson e NOGUEIRA, Marco Aurélio (org.). (1988) Gramsci e a América Latina. Rio de Janeiro. Paz e 
Terra.

DA VIÁ, Sarah Chucid (1977) Televisão e consciência de classe. Rio de Janeiro. Vozes.

ESCOSTEGUY, Ana Carolina. (2001) Cartografia dos estudos culturais: uma visão latino-americana. Belo Horizonte. Autêntica.

ESCOSTEGUY, Ana Carolina. (1993) "A pesquisa do popular na comunicação: uma análise metodológica". Dissertação de mestrado. ECA/USP.

FISCHER, Rosa Maria Bueno (1982) 0 mito na sala de jantar. Porto Alegre. Editora Movimento.

GOLDFEDER, Miriam (1980) Por trás das ondas da Rádio Nacional. Rio de Janeiro. Paz e Terra.

GONZÁLEZ, Jorge (1994). "Los frentes culturales. Culturas, mapas, poderes y luchas por las definiciones legítimas de los sentidos sociales de la vida". In LAMEIRAS, José y CÁCERES, Jesús Galindo. Medios y mediaciones. Guadalajara. ITESO/ Colégio Michoacán.

HERMOSILLA, Maria Elena (s/d) Explorando la recepción televisiva. 15 técnicas para indagar la relación entre los televidentes y los mensajes televisivo. Santiago do Chile: CENECA/CENCOSEP.

JACKS, Nilda (1999) Querência. Cultura regional como mediação simbólica: um estudo de recepção. Porto Alegre. Editora da Universidade/ UFRGS, 1999.

JACKS, Nilda. (1996) "Televisión, recepción, identidad: cuestiones e imbricaciones". In OROZCO, Guillermo (org.) Miradas latinoamericanas a la televisión. México. Ensayos del PROIICOM/2.

JACKS, Nilda. (1999) "A pesquisa de Recepção no Brasil: em busca da influência latino-americana". In Lopes, Maria Immacolata (org.). Vinte anos de ciência da comunicação no Brasil. Avaliação e perspectivas. Santos. Intercom/ Unisanta.

JACKS, Nilda e RONSINI, Veneza. (1995) "Mediação na recepção: estudo comparativo entre receptor urbano e rural". In A encenação dos sentidos. Mídia, cultura e política. Rio de Janeiro: COMPÓS/Diadorim.

JACKS, Nilda (1996) "Tendências latino-americanas nos estudos de recepção". Revista FAMECOS , Porto Alegre, N. 5
JACKS, Nilda et alli. (1997) "El receptor de los nuevos medios. Levantamiento bibliográfico". In Comunicación y Sociedad N.29. Universidad de Guadalajara, pp 179191.

JONES, Daniel. (1996) "La comunicación en América Latina". Telos N. 47. Madrid

LEAL, Ondina Fachel (1986) A leitura Social da novela das oito. Petrópolis. Vozes.

LOPES, Maria Immacolata. (1994) "Reflexiones Meto-dológicas Sobre la Investigación de Recepción". In Investigar la Comunicación. Propuestas Iberoamericanas. Universidad de Guadalajara/ALAIC.

LOPES, Maria Immacolata. ( 1988) 0 rádio dos pobres. São Paulo. Loyola.

LOPES, Maria Immacolata. (1995) "Recepção dos meios, classes, poder e estrutura". In Comunicação e Sociedade, São Bernardo do Campo, n. 23, p. 99-110, jun.

LOZANO, Elizabeth. (1991) "Del sujeto cautivo a los consumidores nomadicos". In Dia-logos de la comunicación N.30. FELAFACS.

MARTÍN-BARBERO, Jesús. (1987) De los medios a las media-ciones. México: G. Gilli.

MARTÍN-BARBERO, Jesús (1991) "Recepción: uso de medios y consumo cultural" (presentación). In Revista Dia-logos de la comunicación N.30. FELAFACS, Lima.

MICELI, Sérgio (1972) A noite da madrinha. S. Paulo. Perspectiva.

MILANESI, Luiz Augusto (1978) 0 paraíso via embratel. Rio de Janeiro. Paz e Terra.

MONEDERO, Claudia Herrán (1994) "Un salto no dado: de las mediaciones al sentido", In OROZCO, Guillermo(coord.) Cuadernos de comunicación y practicas sociales n.6. PROIICOM/UIA. México.

OROZCO, Guillermo (coord.) (1996a) Miradas latinoamericanas a la televisión. México. Ensayos del PROIICOM/ 2.

OROZCO, Guillermo (1996) Televisión y audiencias. Un enfoque cualitativo. Madrid. Ediciones de la Torre/ UIA. 
OROZCO, Guillermo. (1991) "Recepción televisiva. Tres aproximaciones y una razón para su estudio". In Cuadernos de Comunicación y Practicas Sociales N² 2. México: PROIICOM/UIA.

PACHECO, Elsa Dias (1985) 0 Pica- Pau: herói ou vilão? São Paulo. Loyola.

RONSINI, Veneza M. (1993) "Cotidiano rural e recepção de TV: o caso Três Barras". Dissertação de Mestrado. ECA/USP.

SAINTOUT, Florencia. Los estudios de recepción en América Latina. La Plata. Universidad de La Plata, 1998.

SARQUES, Jane (1981) "A ideologia sexual dos Gigantes". Dissertação de Mestrado. UnB.

SCHLESINGER, Philip e MORRIS, Nancy. (1997) "Comuni-cación e identidad en América Latina". In Telos N.40. Madrid.

SILVA, Carlos Eduardo Lins da (1985) Muito além do Jardim Botânico. São Paulo. Summus Editorial.

SOUSA, Mauro Wilton.(1986) "Rosa Púrpura de cada dia: trajetória de vida e cotidiano urbano-industrial". Tese de doutorado. ECA/USP.

SOUSA, Mauro Wilton. (1997) "Novos olhares sobre as práticas de recepção em comunicação",.In LOPES, Maria Immacolata Vassalo (org.) Temas contemporâneos em comunicação. São Paulo. EDICOM/ INTERCOM.

TILBURG, João Luis (1987) "Elementos para democratização da televisão no Brasil". Tese de doutorado. ECO/UFRJ.

TRIGUEIRO, Osvaldo (1987) "A TV Globo em duas comunidades rurais da Paraíba". Dissertação de Mestrado. UFPe, Recife.

TUFTE, Thomas (1996) "Estudos de mídia na América Latina", In Revista Comunicação e Sociedade N. 25. pp. 21-47. São Bernardo do Campo.

VVAA (1992) "Educación para la comunicación". Manual Latino-americano. Chile CENECA.

VELÉZ, Marta Elena Montoya. (1992) ¿Un nuevo modelo de comunicación en América Latina?. México: Fundación Manuel Bondía. 